\title{
THE USE OF TRAFFIC SIGN PICTURES TO IMPROVE THE STUDENTS' ABILITY IN CONSTRUCTING IMPERATIVE SENTENCE
}

\author{
Nurhalijah $^{1}$, Ismail Latif ${ }^{2}$ \\ Nurhalijah03@gmail.com \\ English Program, Tarbiyah Faculty, State Islamic Institute of Parepare ${ }^{12}$
}

\begin{abstract}
One of grammatical pattern of English that is important to be taught is imperative sentences. By having the knowledge about imperative sentences, students are supposed to be able to construct the sentences correctly. Although the students have learnt imperative sentences at school, most of them still find difficulties in understanding and using them. This study aimed at finding out whether using of traffic sign pictures able to improve the students' ability in constructing imperative sentence. This study was conducted at the seventh grade of SMPN 2 Tellu Limpoe kabupaten Sidenreng Rappang by using pre-experimental method with one group on pre-test and post-test design. This study was conducted in eight meeting which consist of one meeting for pre-test, six meeting for treatment, and one meeting for post-test. The data were gathered through quantitative data. The study found out the use of traffic sign pictures was able to improve the students' ability in constructing imperative sentence. This study also provides a set of recommendation to avoid the overlapped researches in English education.
\end{abstract}

Keywords: traffic sign, imperative sentence

\section{Introduction}

Language is one important communication instrument, especially for human beings. By using language, people can easily communicate to each other, because language is the most effective tool of communication. Language is also used to deliver message, express ideas, thought and one's feeling to others.

Allah SWT also created different languages for human beings, He says in The Holy Qur"ean in Surah Ar-Ruum verse 22 as follows:

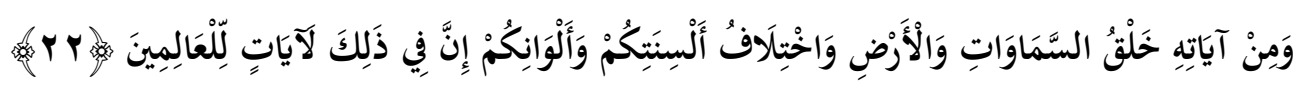

Translate: "And among His Signs is the creation of the heavens and the earth, and the variations in your languages and your colors: verily in that are Signs for those who know."

Language learning is important for human's social development. As a language which is used by more than a half of population in the world, English holds the key as international language. English is a tool of communication among peoples of the world to get trade, social-cultural, science, and technology goals. Moreover, English competence is important in career development, therefore students need to understand and use English to improve their confidence to face global competition. 
In learning a foreign language, particularly English, mastering its vocabulary is not enough without mastering its grammar. The words, which are uttered by someone who are learning the language, will not be meaningful without having them arranged in a certain grammatical pattern appropriately. In order to give a message, a speaker will not be understood if he just says the words without arranging them. The fact shows that the result of teaching learning English is still low.

The students have learned from the first-grade of junior high school until senior high school, but most of them still cannot use English as tool of communication. Besides, their abilities are also below the expectation. For example, the students who have graduated from senior high school, they still find difficulty in constructing imperative sentences. Actually, the students can't understand what the other people or their teacher asks.

According to data of the researches, there are two researches show that students' understanding of imperative sentence is low. In junior high school level, data shows that the highest score is 67,5 and the lowest score is 32,5 (Sutikno, 2014). Meanwhile, in senior high school level, data shows that the highest score is 69,5 and the lowest score is 30 (Adawiyah, 2015). It can be concluded that there is no students who passed the Minimum Mastery Criterion (KKM).

One of grammatical pattern of English that is important to be taught is imperative sentences. By having the knowledge about imperative sentences, students are supposed to be able to construct the sentences correctly. It is component should be known and understood well by students if they want to understand English lesson well. By knowing and learning about Imperative sentences, students can also understand what they read and write or listen well.

Although the students have learnt imperative sentences at school, most of them still find difficulties in understanding and using them. They think that imperative sentence has confusing rules and sometimes they feel bored when learning it. Therefore, they try to avoid it. Some students also think that imperative sentence is full of pattern which students are supposed to understand it. To solve this problem, it is important to find another way in conveying the material in order to minimize the students' difficulties in learning imperative sentence and make them understand how to use it.

One of the ways to make the students more interested in their learning process especially in grammar lesson is by using a media. There are many kinds of media that the teacher may choose in teaching and learning process. One of them is 
visual media; it is a picture to teach imperative sentence. Pictures are not just an aspect of method, but through their representation of place, object and people essential parts overall experience (Wright, 2004).

Based on the observation that conducted by the writer about teaching imperative sentence at seventh grade students of SMPN 2 Tellu Limpoe Sidrap, the writer found that the most of students have some problems in using imperative sentences such as: first, the students still have limited vocabularies, so they felt difficult to make a sentence when they asked someone to do something, and they forgot a new vocabularies easily even through the teacher has just been given them. Second, the students are still difficult in understanding the sign's mean that they usually ever seen in some places. Third, the students only understand about command because their mind has been set that imperative sentence is kalimat perintah. They know about imperative sentence just like sit down, open the door, clean the whiteboard, etc.

Based on the problem above, the writer wants to propose the solution in improving students' ability in constructing imperative sentence by using traffic sign pictures. The writer considers that picture can be an effective and helpful medium to motivate students in learning English. Therefore, the writer chooses the traffic sign picture as the media to convey the material especially in teaching imperative sentence to make them more interesting. Because the traffic sign pictures contain information that relating with imperative sentence.

\section{Method}

This study was called quantitative research because it will used numbers of statistic. The method of this research was pre-experimental model with one group pre-test post-test design.

The study was done at the seventh-grade students of SMPN 2 Tellu Limpoe Kabupaten Sidenreng Rappang, and the duration of the study was about one months. It was started from Monday, July $30^{\text {th }} 2018$ until Wednesday, August $29^{\text {th }} 2018$.

The population of this study was the whole of seventh grade students of SMPN 2 Tellu Limpoe Kabupaten Sidenreng Rappang. The total of the seventhgrade students was 56 people. There were two classes comprising VII-1 and VII-2.

The writer used group random sampling technique to determine the sample, so she just took one class based on the recommendation of English teacher. Based on the English teacher's argument, he said that the level of Students' ability in VII-2 
class was lower than VII-1 class. Therefore, he recommended to the writer to take VII- 2 class as sample of the research which consisted of 27 students (12 male and 15 female).

The writer used 4 item tests in the instrument. It was included of multiple choice items, rearrangement items, completion items, and transformation items. Each item consisted of 5 questions.

The technique of data collecting was in chronological order as below:

1. Pre-test

The writer gave a pre-test to the students before the treatment was done. As the writer had discussed in the instrument of the research, the form of the test that was given to the students consisted of 4 test items. The objective of giving pre-test was to know the basic knowledge of the students before the treatment was done.

\section{Treatment}

Treatment was given six times. It conducted after pre-test that was given in the classroom. Procedure of the treatment in each meeting was same, but the material was different in each meeting.

The material which was taught consists of command, request, invitation, suggestion, advice and prohibition. It is taught from the first meeting until the six meeting chronologically. Whereas, teaching methodology that was used by the writer in the class namely silent way method. Procedures in each meeting as follows: 1) the writer opened the lesson, 2) the writer gave the representation of material, 3) the writer divided students until five groups, 4) every groups were asked to do the worksheet, 5) sstudents asked to the writer about what their difficulties, 6) The writer explained what the students asked

\section{Post-test}

The last step was giving post-test to the students after the treatment was given. The test that was used for post test was the same as the test that was used for pre-test. It consisted of 4 test items. The objective of giving post-test was to know students' learning achievement after the treatment was given.

The data collected through the test was analyzed quantitatively. This quantitative analysis employed statically calculation to the test the hypothesis. It was called paired sample t-test.

$$
t=\frac{\overline{\mathrm{D}}}{\sqrt{\frac{\Sigma D^{2}-\left(\frac{\Sigma D}{N}\right)^{2}}{N(N-1)}}}
$$


Where:

$\mathrm{t} \quad=$ Test of significance

D $=$ The mean score of the difference

$\Sigma \mathrm{D}=$ The square of the sum score for defiance

$\mathrm{N} \quad=$ The total number of student

$\left(\sum \mathrm{D}\right)^{2}=$ The square of $\sum \mathrm{D}$

$\mathrm{N} \quad=$ The number of subject

To the hypothesis, the research used two-tailed test with 0,05 level of significance. For independent sample, the formula of freedom (df) is N-1

1. If t-table $<$ t-test, $\mathrm{H}_{1}$ is fail rejected. and $\mathrm{H}_{0}$ is rejected. It means that using traffic sign pictures able to improve students' ability in constructing imperative sentence.

2. If t-test $<\mathrm{t}$-table value $\mathrm{H}_{0}$ is fail rejected and $\mathrm{H}_{1}$ is rejected. It means that using traffic sign pictures unable to improve students' ability in constructing imperative sentence.

\section{Finding}

After conducting the research, the writer obtained two kinds of data; the scores of pre-tests and the scores of post-tests. The writer had given to the students a pre-test and post-test which consist of 20 questions. The test was done two times, pre-test was given before giving treatment and post-test was given after giving treatment.

Table 1 The Overall Result of Pre-test and Post-test

\begin{tabular}{ccc}
\hline Respondent & Pre-test & Post-test \\
\hline 001 & 58 & 74 \\
002 & 54 & 68 \\
003 & 32 & 48 \\
004 & 28 & 58 \\
005 & 32 & 40 \\
006 & 38 & 50 \\
007 & 58 & 78 \\
008 & 52 & 74 \\
009 & 28 & 50 \\
010 & 30 & 60 \\
011 & 28 & 58 \\
012 & 38 & 46 \\
013 & 30 & 56 \\
\hline
\end{tabular}


7nspiring: English Education Journal

Volume 2 No 2 September 2019

\begin{tabular}{ccc}
\hline 014 & 28 & 54 \\
015 & 52 & 68 \\
016 & 30 & 46 \\
017 & 34 & 60 \\
018 & 32 & 66 \\
019 & 24 & 38 \\
020 & 30 & 56 \\
021 & 32 & 66 \\
022 & 34 & 48 \\
023 & 28 & 66 \\
024 & 50 & 68 \\
025 & 56 & 72 \\
026 & 44 & 56 \\
027 & 30 & 46 \\
\hline Total & $\mathbf{1 0 1 0}$ & $\mathbf{1 5 7 0}$ \\
\hline Mean Score & $\mathbf{3 7 . 4 1}$ & $\mathbf{5 8 . 1 5}$ \\
\hline
\end{tabular}

Table 2 The T-test Analysis

\begin{tabular}{ccccc}
\hline Respondent & Pre-test & Post-test & D & $\mathbf{D}^{\mathbf{2}}$ \\
\hline 001 & 58 & 74 & 16 & 256 \\
002 & 54 & 68 & 14 & 196 \\
003 & 32 & 48 & 16 & 256 \\
004 & 28 & 58 & 30 & 900 \\
005 & 32 & 40 & 8 & 64 \\
006 & 38 & 50 & 12 & 144 \\
007 & 58 & 78 & 20 & 400 \\
008 & 52 & 74 & 22 & 484 \\
009 & 28 & 50 & 22 & 484 \\
010 & 30 & 60 & 30 & 900 \\
011 & 28 & 58 & 30 & 900 \\
012 & 38 & 46 & 8 & 64 \\
013 & 30 & 56 & 26 & 676 \\
014 & 28 & 54 & 26 & 676 \\
015 & 52 & 68 & 16 & 256 \\
016 & 30 & 46 & 16 & 256 \\
017 & 34 & 60 & 26 & 676 \\
018 & 32 & 66 & 34 & 1156 \\
019 & 24 & 38 & 14 & 196 \\
020 & 30 & 56 & 26 & 676 \\
021 & 32 & 66 & 34 & 1156 \\
022 & 34 & 48 & 14 & 196 \\
023 & 28 & 66 & 38 & 1444 \\
024 & 50 & 68 & 18 & 324 \\
025 & 56 & 72 & 16 & 256 \\
026 & 44 & 56 & 12 & 144 \\
& & & &
\end{tabular}




\begin{tabular}{ccccc}
027 & 30 & 46 & 16 & 256 \\
\hline Total & & $\mathbf{5 6 0}$ & $\mathbf{1 3 1 3 6}$ \\
\hline$\overline{\mathbf{D}}$ & \multicolumn{3}{c}{$\mathbf{2 0 . 7 4}$} \\
\hline t-test & \multicolumn{3}{c}{$\mathbf{4 . 8 8}$} \\
\hline
\end{tabular}

\section{Discussion}

Based on the result of the data analysis, mean of the students' score after giving treatment were higher than before giving treatment. Mean score of pre-test was 37.41 while mean score of post-test was 58.15. It proved that the students' score in constructing imperative sentence by using traffic sign pictures was better although it's still distant from Minimum Mastery Criterion (KKM). Besides, the result of t-test analysis showed that $\mathrm{t}$-test value (4.88) was higher than $\mathrm{t}$-table value (2.05). It meant that the use of traffic sign pictures was able to improve the students' ability in constructing imperative sentence. Another reason based on the students' responses was because most students found that using traffic sign pictures was enjoyable.

After conducting the research, the writer found that the students really looked excited with using of traffic sign pictures as medium to teach imperative sentence. So, they followed the teaching and learning process enthusiastically. The existence of the pictures helped the students to understand the material and to get the meaning of a certain words. Thus, traffic sign pictures would not be really difficult for the students. They have felt familiar with the picture because they find it almost every day.

But the problem that they faced mostly is lack of basic knowledge about English and lack of vocabulary. The writer knew about that case after telling the students about it. They said that they didn't know about English because they seldom get it in elementary school. If they seldom studied English when they were in elementary school, then they didn't have vocabularies more. Practically, some students admitted that they got vocabulary not in school but when they played the game. Therefore, they got trouble in answering the test that was given by the writer.

Based on the statement of the writer, it said that the most of students had some problems in using imperative sentence. It is proved by the mean score of students' pre-test which was very poor. But, there were some factors that were influenced the students in constructing imperative sentence after they got the treatment using traffic sign pictures.

In giving treatment, the writer used material which was made by her. According to Fininochiaro's argument, a good picture should be large enough to be seen by all students and as simple as possible. Therefore, material that was used by 
the writer in teaching imperative sentence was clear to be seen and as simple as possible. Moreover, based on the Wright's argument in the same chapter, pictures should be interesting for the student. So, the writer took traffic sign picture that was close by the daily life of students. Meanwhile, material about imperative sentence was taken from Juwita Magdalena's thesis. She explained about functions of imperative sentence.

According to Celce-Murcia and Hilles, they stated that interesting and entertaining picture motivate student to respond in ways that more routine teaching aids. It was proved by the writer when she taught in class. Although her material used traffic sign pictures, yet the writer used a board and marker occasionally. Consequently, the students more liked to learn by using traffic sign pictures than using board and marker. When it used traffic sign pictures, students paid attention to the writer's explanation and more active in responding her. Nevertheless, it was inversely proportional with using a board and marker. The students felt bored until they didn't pay attention to the writer's explanation. As it did so, Li-Shing stated that the benefits of using pictures were pictures can add students' interest and attract their attention.

As a result, the writer can draw a conclusion that the use of traffic sign pictures was more effective and efficient to improve the students' ability in constructing imperative sentence at the seventh-grade students of SMPN 2 Tellu Limpoe Kabupaten Sidenreng Rappang. It was supported by the statement of Natawidjaya.

\section{Conclution}

The writer concluded the research result that the use of traffic sign pictures was able to improve students' ability in constructing imperative sentence at the seventh-grade students of SMPN 2 Tellu Limpoe Kabupaten Sidenreng Rappang. It was proven by the t-test value that was 4,88 which was higher than 2,056 as the $t$ table value. Besides, there was a significant difference between the students' ability in constructing imperative sentence at the seventh-grade students of SMPN 2 Tellu Limpoe Kabupaten Sidenreng Rappang before and after giving treatment. It was proven by the mean score of pre-test that was 37.41 then improved to 58.15 as the mean score of post-test. It meant that quality of the students' ability in constructing imperative sentence improved from "very poor" to "fair" after using traffic sign pictures in giving treatment. 
7uspiring: English Education Journal

Volume 2 No 2 September 2019

\section{References}

Adawiyah, Rabiatul. 2009. The Students' Ability in Constructing Imperative Sentences of the Eleventh Grade at Science and Islamic Indonesian Letter of MAN Pelaihari Academic Year 2009/2010. IAIN Antasari Repository.

Gay, L.R. 1981. Educational Research (Columbus, (ohio), Charles E. Meril Publishing.

Sutikno. 2014. An Error Analysis on the Students' Ability in Imperative Sentence. Purwokerto: UMP Repository.

Wright, Andrew. 2004. Pictures for Language Learning. New York: Cambridge University Press. 